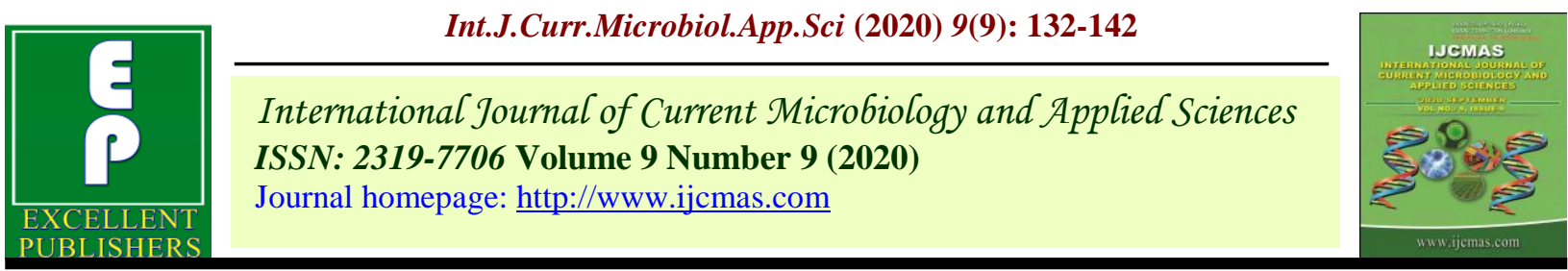

\title{
Estimation of Combining Ability for Yield and Yield Component in Green Gram (Vigna radiata (L.) Wilczek)
}

\author{
S. R. Hange*, S. R. Shinde and V. S. Pawar \\ Department of Genetic and plant Breeding, Mahatma Phule Krishi Vidyapeeth, \\ Rahuri-413722 (M.S), India \\ *Corresponding author
}

\section{A B S T R A C T}

\begin{abstract}
The present study consisted of six female parents and three male parents. The crosses among the females and males were effected in line $\times$ tester $(6 \times 3)$. The resulting $18 \mathrm{~F}_{1} \mathrm{~s}$ were evaluated along with the nine parents and one check (PKV Green gold) in Randomized Block Design with three replications. The observations on five randomly selected plants in each replication was recorded for twelve characters viz., days to 50 per cent flowering, days to maturity, plant height $(\mathrm{cm})$ and grain yield per plant $(\mathrm{g})$. Among the parents, females BPMR-145 and AKM8802 and AKM-10-07 from males were found best general combiner for grain yield per plant out of eighteen cross combination vaibhav x AKM-10-07 exhibited superior performance for plant height and grain yield, BM-2003 x AKM-10-13 for seed weight and grain yield, BM2003 x AKM-0603 for grain yield and flower to pod ratio BPMR-145 x AKM-10-07 earliness and grain yield per plant. There for these hybrids are recommended for heterosis breeding to boost low yield levels of green gram. The hybrids with non significant SCA effects (absence of dominance) and parent with significant GCA effect (presence of additive gene action) are useful in identification of identification of superior segregants. Therefore the hybrids BM-2002 x AKM-10-13, BM-2002 x AKM-0603, PM-402 x AKM-10-07, PM-402 x AKM-0603, BPMR-145 x AKM-0603, AKM-8802 x AKM-10-07 and AKM-8802 x AKM-10-13 had exhibited non significant sca effect (Absence of dominance) and parents with significant and positive GCA effects (additive gene action) for different yield and yield contributing characters are recommended for recombination breeding with pedigree method of selection.
\end{abstract}

\section{Introduction}

Mungbean is an important pulse crop. Pulses are one of the important segments of Indian agriculture after cereals in production. It is considered to be the hardiest among the pulse crops. On an average, pulses contain 20 to 30 percent protein, which is almost 2.5 to 3.0 times the value normally found in cereals. Besides their high nutritional value, they have unique characteristics of maintaining and restoring soil fertility through biological nitrogen fixation and thus play a vital role in sustainable agriculture. The important pulse crops grown in India are bengal gram, lentil, green gram, black gram, cowpea, red gram and pea. Sprouted mungbean are used as fresh vegetable making noodles and other textured preparations. It is rich in vitamin B and regarded as remedy for the disease Beriberi. 
When it is allowed to sprout, ascorbic acid (Vit. $C$ ) is synthesized. The amount of riboflavin and thiamin in mungbean are also high. It contains 24 per cent proteins with all essential amino acids. India is prime mungbean producer, contributing about 75 per cent of the world production. Among the pulses grown in India, it ranks third after chickpea and red gram. The major mungbean producing states are Andhra Pradesh, Maharashtra, Gujarat, Orissa and Tamilnadu. About 70 per cent of mungbean is cultivated during Kharif season, while remaining 30 per cent is grown in Rabi and Summer season.

Several plant researchers have emphasized on the use of heritability and genetic advance in identification of desirable populations in legumes (Malik et al., 1983; Development of a new variety with high yield, long pod, bold seed, non-shattering and having stable performance is the main aim of all the plant breeders. Earliest step in a successful crop breeding program is to select appropriate parents. The success of most crop improvement programs largely depends upon the genetic variability and the heritability of desirable traits. The magnitude and type of genetic variability helps the breeders to determine the selection criteria and breeding schemes to be used for improvement purposes. For any planned mungbean breeding program to improve seed yield potential through important parameters of crops, it is necessary to obtain adequate information on the magnitude and type of genetic variability and their corresponding heritability.

The line $\times$ tester technique has been extensively used in almost all the major field crops to estimate GCA and SCA variances and effects and to understand the nature of gene action involved in the expression of various quantitative traits. This technique measures the GCA and SCA variances and effects and the genetic components of variance. It however, fails to detect and estimate the epistatic variance.

\section{Materials and Methods}

The present study was undertaken on Line $x$ Tester analysis in which set of 18 different crosses, 9 inbred lines, comprising 6 females and 3 males and 1 check were used showed in table 1 . The inbred lines were collected from the Principal Scientist, Pulses Improvement Project M.P.K.V. Rahuri, Genotype possessing diversity for yield and other component were selected.

Total 18 crosses were affected. The cross seed was obtained at Post Graduate Research Farm, College of Agriculture, Kolhapur. The hybrids (18) along with parents (9) and 1 check were grown and tested in RBD with three replications. All possible care was taken at the time of pollination to avoid contamination. The crossing was done in line $\times$ tester fashion and selfing of parents to obtain seeds of 18 crosses and 9 parents. All the package of practices was followed for good crop growth.

Five random plants from each treatment in each replication were selected for recording observations. The selected plants were tagged at the age of 30 days. The observations on five randomly selected plants in each replication was recorded for twelve characters viz; days to 50 per cent flowering, days to maturity, plant height, branches per plant, pods per plant, 100 seeds weight(g), grain yield per plant $(\mathrm{g})$, seeds per pod, flower to pod ratio percent, percent number of flower dropped, protein content (percent) and pod shattering.

\section{Results and Discussion}

The analysis of variance for combining ability is presented in Table 2. The variances due to females were significant for plant height and 
flower to pod ratio and for rest of the characters it was observed to be nonsignificant. The variances for combining ability due to males were not found to be significant for any character. The variance due of female $\times$ male interaction was observed to be significant for days to maturity, plant height, branches per plant, grain yield per plant, flower to pod ratio and percent flower drop indicating substantial variability produced by the hybrids for these different characters. The magnitudes of variances due to females were greater than those due to male and females $\times$ male interaction for days to 50 per cent flowering, days to maturity, plant height, branches per plant flower to pod ratio, and protein content. The magnitudes were lower than males; female $\times$ male interaction for pods per plant and a seed per pod provides the information about role females and males to express these characters. The values of variances due to female were higher than those due to female $x$ male interaction for all the characters except pods per plant, seeds per pod and 100 seeds weight.

The estimates of general combining ability effects of females and male and specific combining ability effects for the hybrids were presented in Table 3 and 4, respectively and explained as given below

\section{General combining ability effects of parents}

Estimates of general combining ability effects are given in Table 3.

\section{Days to 50 per cent flowering}

An examination of the general combining ability effects for days to 50 per cent flowering revealed that females and males showed their poor combining ability in expression of the character under study. The variance duo to general combining ability $\delta 2$ gca was greater than that due to specific combining ability $\delta_{2}$ sca depicting nonadditive gene action for days for 50 percent flowering restricting application of selection from segregating generations. These results are in conformation with those reported by Khattak et al., (2001), and Barad et al., (2008).

\section{Days to maturity}

The female BM-2003 and PM-402 exhibited significant negative gca effect for days to maturity indicating their readiness to transfer earliness from them to their progeny. However none of the male parent had produced significant negative gca effects to induce earliness. Similar results were also reported by Singh and Singh (1972a), Ahuja (1980) and Deshmukh and Manjare (1980).

\section{Plant height (cm)}

The female vaibhav had expressed significant positive general combining ability effects. for the character indicating its potential to improve the character.

While male AKM-10-07 had shown some promise for combining ability to express this character. These result are in accordance with earlier report made by Pokle and Nomulvar (1975), Choudhary (1986), (1988), and Barad et al., (2008).

\section{Branches per plant}

The female BM-2002 and PM-402 had produce significant positive gca effects, showing suitability of these genotypes to use as parents for improvement of this character through hybridization. The gca effects of males were non significant for the character. Similar results were reported by Choudhary (1986), and H. R. Barad et al., (2008). 


\section{Pod per plant}

The only female BM-2003 had highest significant gca effects for such an important yield contributing character. Therefore this can be used as one of the parent to improve yield in various hybridization program. However the male AKM-10-13 had positive gca effect for the character. These results are in conformation with those reported by Singh and Singh (1971a), Singh and Jain (1972b), Ahuja (1980), Deshmukh and Manjare (1980), Choudhary (1986), Singh et al., (2007), Barad et al., (2008).

\section{0 seeds weight $(\mathrm{g})$}

None of the female had produce significant positive gca effects for the character under study. While vaibhav,BPMR-145 and AKM8802 displayed their desirable performance producing positive gca effects. None of the male had exhibited significant positive gca effect for the character. Similar results were reported by Singh and Singh (1972a), Ahuja (1980), Deshmukh and Manjare (1980), Kute et al., (2002) and Barad et al., (2008),

\section{Grain yield per plant (g)}

The female BPMR-145 (5.82) had highest significant positive gca effect followed by AKM-8802(2.89) indicating these are the best females that can be used in hybridization program to improve such an important character. The gca performance of these females is in confirmation with the highest mean per se performance Viz. BPMR-145 (20.01) and AKM-8802 (16.47). None of the male parent had produced significant positive gca effect for the character. These results are in conformation with those reported by Choudhary (1986).

\section{Seeds per pod}

None of the female and male displayed significant positive gca effect for the character under investigation. Similar results were also reported by Ahuja (1980), Manjare et al., (1980), (1988), Khattak et al., (2001), H. R. Barad et al., (2008).

\section{Flower to pod ratio (percent)}

The female BM-2002 (10.63) produce highest gca effect among the females followed by BPMR-145 (2.58). The performance of BPMR-145 was in accordance to highest mean per se performance (20.01) for the character. Among the males AKM-10-13 and AKM-0603 had produced positive gca effects for the character under study.

\section{Percent flower drop}

The female vaibhav displayed highest significant negative gca effect (-6.73) followed by BM-2002 (-1.31) indicating less percent of flower dropped. So these female can be used in hybridization program for improvement of the character. The male AKM-0603 recorded (-2.28) significant negative gca effect for the character

\section{Protein percent}

The female BM-2002 and AKM-8802 had significant positive gca effects for protein percent therefore these are the promising females for the improvement of the character under study. The male AKM-10-13 displayed significant positive gca effect for protein percent. These results are in conformation with those reported by Singh and Singh (1971a), Ahuja (1980), Deshmukh and Manjare (1980), Khattak et al., (2001) and Barad et al., (2008). The parent $\mathrm{L}_{2}, \mathrm{~L}_{3}, \mathrm{~L}_{4}, \mathrm{~L}_{5}$, $\mathrm{L}_{6}$ and $\mathrm{T}_{1}$ recorded positively significant gca effects and superior mean performance for various yield and yield contributing characters. Therefore a multiple crossing program involving all these parents will result in identification of superior genotypes for different yield and yield contributing characters. 
The parents showing high general combining ability for different characters have been presented in Table No. 3.

Specific combining ability effects of hybrids

\section{Days to $\mathbf{5 0}$ per cent flowering}

The only cross BM-2002 x AKM-10-07 had showed significant negative sca effect for days to 50 percent flowering indicating the expression for earliness. Seven crosses displayed negative heterosis for the character under study. These results are in confirmation with mean performance of hybrids. These finding are in agreement with earlier report made by Singh and Singh (1972a), Ahuja (1980), Deshmukh and Manjare (1980), and Jahagirdar (2001).

\section{Days to maturity}

The crosses viz BM-2002 x AKM-10-07, vaibhav x AKM0603, BPMR-145 x AKM10-07 and AKM-8802 $\mathrm{x}$ AKM-10-13 expressed significant negative sca effects indicating induction of early maturity in these combinations. These result are in accordance with earlier report made by Jahagirdar (2001).

Table.1 List of parents, hybrids and check

\begin{tabular}{|l|l|l|l|}
\hline $\begin{array}{l}\text { Treat. } \\
\text { No. }\end{array}$ & Genotypes & $\begin{array}{l}\text { Treat. } \\
\text { No. }\end{array}$ & \\
\hline & Female & & Hybrids \\
\hline $\mathbf{1}$ & BM-2002-1 & 1 & BM2002xAKM10-07 \\
\hline $\mathbf{2}$ & Vaibhav & 2 & BM2002xAKM-10-13 \\
\hline $\mathbf{3}$ & PM-402 & 3 & BM2002xAKM0603 \\
\hline $\mathbf{4}$ & BM-2003-2 & 4 & VibhavXAKM10-07 \\
\hline $\mathbf{5}$ & BPMR-145 & 5 & VaibhavXAKM10-13 \\
\hline $\mathbf{6}$ & AKM-8802 & 6 & VaibhavXAKM0603 \\
\hline & & 7 & BM2003xAKM10-07 \\
\hline & Male & 8 & BM2003xAKM10-13 \\
\hline $\mathbf{1}$ & AKM-10-07 & 9 & BM2003xAKM0603 \\
\hline $\mathbf{2}$ & AKM-10-13 & 10 & PM402xAKM10-07 \\
\hline $\mathbf{3}$ & AKM-0603 & 11 & PM402xAKM10-13 \\
\hline & & 12 & PM402xAKM0603 \\
\hline & Check & 13 & BPMR145xAKM10-07 \\
\hline $\mathbf{1}$ & PKV Green gold & 14 & BPMR145xAKM10-13 \\
\hline & & 15 & BPMR145xAKM0603 \\
\hline & & 16 & AKM8802xAKM10-07 \\
\hline & & 17 & AKM8802xAKM10-13 \\
\hline & & 18 & AKM8802xAKM0603 \\
\hline
\end{tabular}


Table.2 Analysis of variance for combining ability

\begin{tabular}{|c|c|c|c|c|c|c|c|c|c|c|c|c|c|}
\hline $\begin{array}{l}\text { Sr. } \\
\text { No. }\end{array}$ & $\begin{array}{l}\text { Source of } \\
\text { Variation }\end{array}$ & DF & $\begin{array}{c}\text { Days } \\
\text { to50\% } \\
\text { flowering }\end{array}$ & $\begin{array}{l}\text { Days to } \\
\text { Maturity }\end{array}$ & $\begin{array}{c}\text { Plant } \\
\text { height } \\
(\mathbf{c m})\end{array}$ & $\begin{array}{l}\text { Branches } \\
\text { / plant }\end{array}$ & Pods/ Plant & $\begin{array}{c}100 \text { Seeds } \\
\text { Weight }\end{array}$ & $\begin{array}{c}\text { Grain } \\
\text { yield / } \\
\text { plant }\end{array}$ & $\begin{array}{l}\text { Seeds/ } \\
\text { Pod }\end{array}$ & $\begin{array}{l}\text { Flower to } \\
\text { pod ratio }\end{array}$ & $\begin{array}{c}\text { Percent } \\
\text { flower } \\
\text { drop }\end{array}$ & Protein \\
\hline 1 & Female & 5 & 1.42 & 5.30 & $12259 *$ & 1.98 & 233739.30 & 0.41 & 217.27 & 0.19 & $393.29 *$ & 127.50 & 13.61 \\
\hline 2 & Male & 2 & 0.05 & 1.24 & 78.43 & 0.10 & 253978.30 & 0.11 & 41.92 & 1.42 & 20.30 & 70.90 & 3.93 \\
\hline 3 & $\begin{array}{c}\text { Female x } \\
\text { Male }\end{array}$ & 10 & 0.87 & $2.68 * *$ & $220.92 * *$ & $0.62 * *$ & 247902.10 & 0.44 & $81.69 * *$ & 0.96 & $92.12 * *$ & $69.86 * *$ & 6.34 \\
\hline 4 & Error & 34 & 0.46 & 0.41 & 12.71 & 0.09 & $\begin{array}{c}2493221.6 \\
0\end{array}$ & 0.24 & 11.12 & 0.47 & 8.71 & 6.32 & 0.40 \\
\hline 5 & $\begin{array}{l}\delta_{2} \text { g.c.a. } \\
\text { for lines }\end{array}$ & & 0.10 & 0.54 & 134.25 & 0.20 & 7510.22 & 0.02 & 23.20 & -0.01 & 42.69 & 12.44 & 1.46 \\
\hline 6 & $\begin{array}{c}\delta_{2} \text { g.c.a. } \\
\text { tester }\end{array}$ & & -0.02 & 0.04 & 3.37 & 0.00 & 4879.50 & -0.03 & 1.85 & 0.05 & 0.62 & $3.07 \mathrm{~s}$ & 0.19 \\
\hline 7 & $\begin{array}{c}\delta_{2} \text { S.c.a. } \\
\text { for } L \times T\end{array}$ & & 0.14 & 0.76 & 67.77 & 0.17 & 27251.63 & 0.08 & 24.41 & 0.19 & 27.69 & 18.11 & 1.96 \\
\hline
\end{tabular}

G.C.A. and S. C. A. effects for parents and their crosses 
Table.3 The estimates of the general combining ability effects for eleven characters in Green gram

\begin{tabular}{|c|c|c|c|c|c|c|c|c|c|c|c|c|}
\hline $\begin{array}{l}\text { Sr. } \\
\text { No. }\end{array}$ & Parents & \begin{tabular}{|c|} 
Days to \\
$50 \%$ \\
flowering
\end{tabular} & $\begin{array}{l}\text { Days to } \\
\text { Maturity }\end{array}$ & $\begin{array}{c}\text { Plant } \\
\text { height } \\
(\mathrm{cm})\end{array}$ & $\begin{array}{c}\text { Branches } \\
\text { /plant }\end{array}$ & $\begin{array}{c}\text { Pods/PI } \\
\text { ant }\end{array}$ & $\begin{array}{c}100 \\
\text { Seeds } \\
\text { Weight }\end{array}$ & $\begin{array}{c}\text { Grain } \\
\text { yield / } \\
\text { plant }\end{array}$ & $\begin{array}{c}\text { Seeds/ } \\
\text { Pod }\end{array}$ & $\begin{array}{l}\text { Flower to } \\
\text { pod ratio }\end{array}$ & $\begin{array}{c}\text { Percent } \\
\text { flower } \\
\text { drop }\end{array}$ & Protein \\
\hline 1 & 2 & 3 & 4 & 5 & 6 & 7 & 8 & 9 & 10 & 11 & 12 & 13 \\
\hline \multicolumn{13}{|c|}{ Females } \\
\hline 1 & BM-2002 & 0.55 & $0.57 * *$ & 3.46 & $0.65 * *$ & -37.04 & -0.22 & 3.70 & 0.09 & $10.63 * *$ & -1.31 & $1.86^{* *}$ \\
\hline 2 & Vaibhav & -0.33 & 0.24 & $21.22 * *$ & 0.09 & -78.40 & 0.17 & $-3.95 * *$ & 0.20 & 1.99 & $-6.73 * *$ & $-1.23 * *$ \\
\hline 3 & BM-2003 & -0.11 & $-1.09 * *$ & $-12.16^{* *}$ & $-0.34 * *$ & $327.53 *$ & -0.25 & $-6.80 * *$ & 0.02 & $-7.28 * *$ & 1.48 & -0.28 \\
\hline 4 & PM-402 & -0.22 & $-0.53^{*}$ & $-7.63 * *$ & $0.38^{* *}$ & -75.95 & -0.08 & -1.67 & -0.20 & $-6.25 * *$ & 0.54 & 0.06 \\
\hline 5 & BPMR-145 & 0.44 & $1.01 * *$ & -2.19 & -0.18 & -64.68 & 0.21 & $5.82 * *$ & 0.02 & $2.58 *$ & 1.75 & $-1.30 * *$ \\
\hline \multirow[t]{4}{*}{6} & $\begin{array}{c}\text { AKM- } \\
8802\end{array}$ & -0.33 & -0.20 & -2.69 & $-0.60 * *$ & -71.44 & 0.17 & $2.89 * *$ & -0.10 & -1.67 & $4.26^{* *}$ & $0.88 * *$ \\
\hline & SE & 0.22 & 0.21 & 1.39 & 0.11 & 135.87 & 0.13 & 0.96 & 0.20 & 1.00 & 1.31 & 0.22 \\
\hline & CD 5\% & 0.44 & 0.42 & 2.84 & 0.22 & 276.12 & 0.28 & 1.97 & 0.40 & 2.03 & 2.66 & 0.45 \\
\hline & CD $1 \%$ & 0.60 & 0.57 & 3.81 & 0.30 & 370.70 & 0.38 & 2.64 & 0.54 & 2.73 & 3.58 & 0.60 \\
\hline
\end{tabular}

$*$,** indicates at $5 \%$ and $1 \%$ level of significant, respectively

\begin{tabular}{|c|c|c|c|c|c|c|c|c|c|c|c|c|}
\hline $\begin{array}{l}\text { Sr. } \\
\text { No. }\end{array}$ & $\begin{array}{c}\text { Parents } \\
\text { Males }\end{array}$ & $\begin{array}{c}\text { Days } \\
\text { to50\% } \\
\text { flowering }\end{array}$ & $\begin{array}{l}\text { Days to } \\
\text { Maturity }\end{array}$ & $\begin{array}{l}\text { Plant } \\
\text { height }\end{array}$ & $\begin{array}{c}\text { Branches / } \\
\text { plant }\end{array}$ & $\begin{array}{c}\text { Pods/Pl } \\
\text { ant }\end{array}$ & $\begin{array}{c}100 \\
\text { Seeds } \\
\text { Weight }\end{array}$ & $\begin{array}{l}\text { Grain } \\
\text { yield / } \\
\text { plant }\end{array}$ & $\begin{array}{c}\text { Seeds/P } \\
\text { od }\end{array}$ & $\begin{array}{c}\text { Flower } \\
\text { to pod } \\
\text { ratio }\end{array}$ & $\begin{array}{c}\text { Percent } \\
\text { flower } \\
\text { drop }\end{array}$ & Protein \\
\hline 1 & 2 & 3 & 4 & 5 & 6 & 7 & 8 & 9 & 10 & 11 & 12 & 13 \\
\hline 1 & AKM-10-07 & 0.00 & 0.29 & 2.17 & 0.05 & -71.76 & 0.04 & $-1.63 *$ & -1.20 & -1.20 & 1.33 & $-0.53 * *$ \\
\hline 2 & AKM-10-13 & -0.05 & -0.20 & -0.19 & -0.08 & 137.11 & -0.09 & 0.25 & 0.79 & 0.79 & 0.94 & $0.33 *$ \\
\hline \multirow[t]{4}{*}{3} & AKM-0603 & 0.05 & -0.09 & -1.98 & 0.03 & -65.34 & 0.05 & 1.38 & 0.41 & 0.41 & $-2.28 *$ & 0.20 \\
\hline & SE & 0.15 & 0.14 & 0.98 & 0.07 & 96 & 0.09 & 0.68 & 0.14 & 0.70 & 0.92 & 0.15 \\
\hline & CD 5\% & 0.31 & 0.30 & 2.09 & 0.16 & 195.24 & 0.20 & 1.39 & 0.28 & 1.44 & 1.88 & 0.31 \\
\hline & CD $1 \%$ & 0.42 & 0.40 & 2.69 & 0.21 & 262.08 & 0.26 & 1.87 & 0.38 & 1.93 & 2.53 & 0.42 \\
\hline
\end{tabular}


Table.4 Estimates of specific combining ability effects for crosses in Green gram

\begin{tabular}{|c|c|c|c|c|c|c|c|c|c|c|c|c|}
\hline $\begin{array}{l}\text { Sr. } \\
\text { No. }\end{array}$ & Parents & $\begin{array}{c}\text { Days to } \\
\mathbf{5 0 \%} \\
\text { flowering }\end{array}$ & $\begin{array}{l}\text { Days to } \\
\text { Maturity }\end{array}$ & $\begin{array}{c}\text { Plant } \\
\text { height }\end{array}$ & $\begin{array}{c}\text { Branches } \\
\text { / plant }\end{array}$ & $\begin{array}{l}\text { Pods/ } \\
\text { Plant }\end{array}$ & $\begin{array}{c}100 \\
\text { Seeds } \\
\text { Weight }\end{array}$ & $\begin{array}{l}\text { grain } \\
\text { yield / } \\
\text { plant }\end{array}$ & $\begin{array}{l}\text { Seeds/ } \\
\text { Pod }\end{array}$ & $\begin{array}{c}\text { Flower } \\
\text { to pod } \\
\text { ratio }\end{array}$ & $\begin{array}{c}\text { Percent } \\
\text { flower } \\
\text { drop }\end{array}$ & Protein \\
\hline 1 & 2 & 3 & 4 & 5 & 6 & 7 & 8 & 9 & 10 & 11 & 12 & 13 \\
\hline \multicolumn{13}{|c|}{ Hybrids } \\
\hline 1 & BM2002xAKM10-07 & $-0.89 *$ & $-1.29 * *$ & $-6.36^{*}$ & 0.12 & 68.18 & 0.34 & -2.44 & 0.17 & 4.41 & $5.84 *$ & 0.26 \\
\hline 2 & BM2002xAKM-10-13 & 0.17 & 0.20 & 2.48 & $-0.86 * *$ & -136.15 & $-0.66 * *$ & 1.81 & $-0.80 *$ & $-7.28 * *$ & $4.92 *$ & $1.32 * *$ \\
\hline 3 & BM2002xAKM0603 & 0.72 & $1.09 * *$ & 3.98 & $0.74 * *$ & 67.96 & 0.31 & 0.62 & 0.63 & $4.89 * *$ & $-10.78 * *$ & $-1.58 * *$ \\
\hline 4 & VAibhavXAKM10-07 & 0.22 & 0.70 & $17.14 * *$ & -0.10 & 66.76 & 0.07 & $6.18 * *$ & 0.52 & 2.66 & -1.74 & 0.31 \\
\hline 5 & VaibhavXAKM10-13 & -0.05 & 0.20 & $-9.78 * *$ & 0.24 & -141.64 & -0.24 & -1.15 & -0.18 & -.29 & -0.96 & -0.72 \\
\hline 6 & VaibhavXAKM0603 & -0.17 & $-0.90 *$ & $-7.36 * *$ & -0.14 & 74.87 & 0.16 & $-5.03 * *$ & -0.34 & -.358 & 2.70 & 0.40 \\
\hline 7 & BM2003xAKM10-07 & 0.33 & -0.18 & 0.31 & -0.03 & 52.61 & -0.44 & $-8.70 * *$ & 0.30 & $-9.730 * *$ & -1.87 & 0.31 \\
\hline 8 & BM2003xAKM10-13 & 0.06 & 0.35 & -3.44 & 0.10 & -126.80 & $0.53 *$ & $3.54 *$ & 0.39 & $5.64 * *$ & 0.98 & $1.05 *$ \\
\hline 9 & ВM2003xAKM0603 & -0.39 & -0.13 & 3.13 & -0.07 & 74.18 & -0.08 & $5.16^{* *}$ & -0.69 & $4.09^{*}$ & 0.89 & $-1.38 * *$ \\
\hline 10 & PM402xAKM10-07 & -0.11 & 0.37 & 2.90 & 0.26 & -329.81 & 0.10 & 0.30 & -0.66 & $4.75^{*}$ & 0.39 & $-1.74 * *$ \\
\hline 11 & PM402xAKM10-13 & -0.06 & 0.20 & -2.37 & 0.17 & $677.24 * *$ & -0.02 & -2.22 & 0.62 & 0.37 & -0.66 & $0.96^{*}$ \\
\hline 12 & PM402xAKM0603 & 0.17 & -0.57 & -0.53 & $-0.44^{*}$ & -347.43 & -0.07 & 1.91 & 0.03 & $-5.11 * *$ & 0.36 & 0.78 \\
\hline 13 & BPMR145xAKM10-07 & 0.33 & $-0.74 *$ & $-5.26 *$ & -0.10 & 72.01 & -0.17 & $3.49 *$ & -0.17 & 0.65 & -2.19 & -0.48 \\
\hline 14 & BPMR145xAKM10-13 & 0.38 & 0.46 & $6.10 *$ & -0.09 & -142.26 & 0.32 & $-5.23 * *$ & -0.01 & -1.60 & -2.54 & $-1.35 * *$ \\
\hline 15 & BPMR145xAKM0603 & -0.72 & 0.35 & -0.83 & 0.19 & 70.25 & -0.14 & 1.74 & 0.19 & 0.99 & 4.64 & $1.80^{* *}$ \\
\hline 16 & AKM8802xAKM10-07 & 0.11 & $1.14^{* *}$ & $-8.73 * *$ & -0.14 & 70.23 & 0.10 & 1.63 & -0.16 & -0.72 & -0.49 & $1.37 * *$ \\
\hline 17 & AKM8802xAKM10-13 & -0.50 & $-1.35 * *$ & $7.07 * *$ & $0.43 *$ & -130.37 & 0.07 & 3.25 & -0.007 & 3.19 & -1.74 & $-1.24 * *$ \\
\hline \multirow[t]{4}{*}{18} & AKM8802xAKM0603 & 0.39 & 0.20 & 1.66 & -0.28 & 60.14 & -0.17 & $-4.41^{*}$ & 0.17 & -2.25 & 2.24 & -0.07 \\
\hline & SE & 0.38 & 0.36 & 2.42 & 0.19 & 235.33 & 0.24 & 1.67 & 0.34 & 1.73 & 2.27 & 0.38 \\
\hline & CD at $5 \%$ & 0.77 & 0.73 & 4.92 & 0.39 & 478.25 & 0.49 & 3.41 & 0.70 & 3.52 & 4.62 & 0.78 \\
\hline & CD at $1 \%$ & 1.04 & 0.99 & 6.60 & 0.52 & 642.08 & 0.65 & 4.58 & 0.94 & 4.73 & 6.20 & 1.04 \\
\hline
\end{tabular}




\section{Plant height (cm)}

The cross vaibhav x AKM10-07 (17.14) produce highest significant positive sca effects followed by AKM-8802 x AKM10-13 (7.07), and BPMR-145 x AKM10-13 (6.10) indicating the best combining ability of the parent involved in the hybridization. Similar results were also reported by Jahagirdar (2001).

\section{Branches per plant}

The parents BM-2002, AKM-0603, AKM8802 and AKM-10-13 had proved their suitability for higher expression of the character under investigation. This was in conformity with previous work reported by Jahagirdar (2001), and Singh and Dikshit (2003).

\section{Pods per plant}

The highest highly significant positive sca effects were produced by PM-402 x AKM10-13 suggesting the potential of the parent to transmit desirable performance from them to their progeny. Similar results were also reported by Singh and Jain (1971b), Jahagirdar (2001), Singh and Dikshit (2003), and Singh et al., (2007).

\section{0 seeds weight $(\mathrm{g})$}

The significant positive sca effects was exhibited by BM-2003 x AKM-10-13 to increase the 100 seeds weight. This was in confirmation with the previous work done by Jahagirdar (2001), and Singh and Dikshit (2003).

\section{Grain yield per plant (g)}

The cross vaibhav $\mathrm{x}$ AKM-10-07 (6.18) exhibited highly significant positive sca effects followed by BM-2003 x AKM0603(5.16), BM-2003 x AKM-10-13 (3.54) and BPMR $-145 \quad \mathrm{x}$ AKM-10-07 (3.49) indicating superior combining ability of the parents involved in the different cross combinations. These expressions are in accordance to mean per se performance of the hybrids. This was in conformity with previous work done by Jahagirdar (2001), and Singh and Dikshit (2003).

\section{Seeds per pod}

None of the hybrid combination had produced significant positive sca effect for the character under study, indicating poor combining ability of the parents involved in the transmission of the character from them to their progeny. These results were in confirmation with the previous work done by Jahagirdar (2001), and Singh and Dikshit (2003).

\section{Flower to pod ratio percent}

Significant positive sca effect for flower to pod ratio was displayed by the combinations Viz.BM-2003 x AKM-10-13 followed by BM-2002 x AKM-0603, PM-402 x AKM-1007 and BM-2003 x AKM-0603. Therefore these hybrids can be utilized for exploitation of benefits of heterosis.

\section{Percent flower drop}

The cross BM-2002 x AKM0603 had displayed highly significant negative sca effect for the character under study, which helps to boost the yield potential of particular cross combination.

\section{Protein percent}

Five cross combinations had produced significant positive sca effect for the protein percent. The cross which BPMR-145 x AKM0603 with highest highly significant positive sca effects. 
This promising expression of particular cross combination is in confirmation with mean per se performance of hybrid. The parents involved in these cross combination may be exploited in various multiple hybridization program for the improvement of protein content which is the important expression of the green gram. This was in confirmation with the previous work done by Jahagirdar (2001), and Singh and Dikshit (2003).

Conclusion of study is as follows:

Among the parents, females BPMR-145 and AKM-8802 and AKM-10-07 from males were found best general combiner for grain yield per plant out of eighteen cross combination vaibhav $\mathrm{x}$ AKM-10-07 exhibited superior performance for plant height and grain yield, BM-2003 x AKM-10-13 for seed weight and grain yield, BM-2003 x AKM-0603 for grain yield and flower to pod ratio BPMR-145 $\mathrm{x}$ AKM-10-07 earliness and grain yield per plant. There for these hybrids are recommended for heterosis breeding to boost low yield levels of green gram. The hybrids with non significant sca effects (absence of dominance) and parent with significant gca effect (presence of additive gene action) are useful in identification of identification of superior segregants.

\section{References}

Ahuja, S. L., 1980, Diallele analysis in $F_{2}$ generation of green gram. Thesis Abstr., 6: 110-111.

Auhja, S. L. and Chowdhury, R. K., 1984, Graphical and component analysis of mungbean Indian J Heredity, 16: 4-10.

Barad, H. R., Pithia, M. S. and Vachhani, J. H., 2008, Heterosis and combining ability studies for economic traits in genetically diverse lines of mungbean (Vigna radiata (L.) Wilczeck). Legume Res., 31 (1): 68-71.
Chowdhury, R. K., 1986, Combining ability analysis for seed yield and its component in mung bean. Crop Improv., 13: 95-97.

Deshmukh, R. B. and Manjare, M. R., 1980, Combining ability in mungbean. Legume Res., 3: 97-101. Jahagirdar, J. E., 2001, Heterosis and combining ability studies for seed yield components in mungbean. Indian $J$. Pulses Res., 14 (2): 141-142

Jahagirdar, J. E., 2001, Heterosis and combining ability studies for seed yield components in mungbean. Indian $J$. Pulses Res., 14 (2): 141-142.

Katiyar R.P. and Katiyar, R.K. 1993. Heterosis and combining effects in chickpea. Indian J. Pulses Research.6(2) :127-131.

Khattak, G. S. S., Haq, M. A., Ashraf, M. and Srinivas, P., 2001, Combining ability in mungbean (Vigna radiata (L.) Wilczek) I. Agronomic traits. Korean J. Crop Sci., 46 (5): 420-423.

Kute, N. S and Deshmukh, R. B., 2002, Genetic analysis in mungbean (Vigna radiata (L.) Wilczek). Legume Res., 25 (4): 258-261.

Luthra,O. P., Kakar,S.N. and Singh, R.K. 1977. Combining ability studies for yield and quality characters in green gram. Hariyana (Agric) Univ. J. Res., 7(4): 200-205.

Malik, B. P. S and Singh, V. P., 1983, Genetics of some metric traits in greengram. Indian J. Agric. Sci. 53: 1002-1005.

Mansuria, C. A., and Joshi, B. C., 1994, Combining ability analysis for polygenic traits in greengram. Gujarat Agric. Univ. Res. J., 19: 78-81.

Mnjare, M.R.1976. Stuudies on heterosis and combining ability in $8 \times 8$ diallel cross of mungbean M.Sc.(Agri.). Thesis submitted to the Mahatma phule Krishi Vidyapeeth, Rahuri. 
Mohar Singh., 2005.Studies of combining ability for physiological traits in urdbean (Vigna mungo L).

Naidu, N. V. and Satyanarayana, A. and Seenaiah, P.1992. Combining ability for yield and yield components in mung bean. Indian J. Pulses Res., 5(2):192194.

Naidu, N. V. and Satyanarayana, A., 1993a, Heterosis and combining ability in mungbean. India J. Pulses Res., 6: 3844.

Patil, A.B., Desai, N.C., Mule, P.N., and Khandelwal, V. 2011. Combining ability analysis in mungbean. Legume Res., 34(3):190-195.

Pokle, Y. S. and Nomulvar, M. T., 1975, Variability studies in some quantitative characters of mung (Phaseolus aureus Roxb.). Punjabrao Krishi Vidyapeeth Res. J., 3: 129-132.

Rao, K.V. and Naur, T. 1979. Line x Tester analysis of combining ability for seed yield in green gram. Madras Agric.J., 66(10):639-642.

Reddy, P. R. and Shreeramulu, C., 1992, Heterosis and combining ability for yield and yield component in mungbean. Genet. Agr., 36: 297-307.

Salimath, P.M., BahL P.N. and Kumar, J.
1988.Genetic analysis for seed protein content in chickpea (Cicer arientum L.) Legume res.ll (2):71-74.

Sarode, N.D., Deshmukh R.B., Patil, J.V., Manjare, M.R. and Mhase, L.B. 2000. Heterosis and combining ability in chickpea. Res. on crops. 1(2): 205-207.

Singh, B. B and Dikshit, H. K., 2003, Combining ability studies for yield and architectural traits in mungbean [Vigna radiata (L.) Wilczek]. Indian J. Genet., 63 (4): 351-352.

Singh, K. B. and Jain, R. P., 1970, Heterosis in mungbean. Indian J. Genet., 30: 251-260.

Singh, K. B. and Jain, R. P., 1970, Heterosis in mungbean. Indian J. Genet., 30: 251-260.

Singh, K. B. and Jain, R. P., 1971a, Analysis of diallel cross in Phaseolus aureus. Theor. Appl. Genet., 41: 271-281.

Singh, R. A., Shiv Kumar., Sanjeev Gupta and Singh, B. B., 2007, Powdery mildew resistant sources in mungbean and their reaction to yellow mosaic disease. J. Food Legumes. 20(1): 98-99.

Singh, T. P and Singh. K. B., 1972a, Combining ability in mungbean. Indian J. Genet., 32: 66-72.

\section{How to cite this article:}

Hange, S. R., S. R. Shinde and Pawar, V. S. 2020. Estimation of Combining Ability for Yield and Yield Component in Green Gram (Vigna radiata (L.) Wilczek). Int.J.Curr.Microbiol.App.Sci. 9(09): 132-142. doi: https://doi.org/10.20546/ijcmas.2020.909.016 